\title{
STUDI LITERATUR HUBUNGAN HIPERTENSI DENGAN KETAJAMAN PENGLIHATAN PADA PENDERITA DIABETES MELLITUS TIPE 2
}

Literature Study of the Relationship of Hypertension and Visual Acuity in Diabetes Mellitus Type II Patients

\author{
Rahman, Masdiana AR, Ningsih Jaya, Nita Sari \\ Politeknik Kesehatan Kemenkes Makassar \\ E-mail : rahman.nasar63@gmail.com
}

\begin{abstract}
Decreased visual acuity is a disorder in the eye that affects vision causing blurred vision. Decreased visual acuity can occur in most DM patients, this is a big threat for people with Diabetes Mellitus because it can cause diabetic retinopathy and even blindness. The purpose of this literature study is structured to present the relationship of hypertension with visual acuity in patients with Type 2 diabetes mellitus. This literature search is carried out to obtain articles that fit the topic through the Google Scholar database by using keywords or Hypertension search with visual acuity in diabetes "OR" hypertension with diabetic retinopathy "AND" healing. The results obtained were 17 articles, which met the criteria of 7 appropriate articles and through a review found to be associated with hypertension with visual acuity in patients with type 2 diabetes mellitus. Risk factors that affect vision can also be caused due to factors age, sex, duration of diabetes mellitus and other complications in sufferers of diabetes mellitus. Based on the results of a literature review and documents related to the relationship between hypertension and visual acuity in patients with type 2 diabetes mellitus, there is a relationship between hypertension and decreased visual acuity. It is recommended that further researchers are expected to be able to pay attention to other variables that contribute to reducing visual acuity.
\end{abstract}

Keywords: Hypertension, visual acuity, diabetes mellitus

\section{ABSTRAK}

Penurunan ketajaman penglihatan merupakan gangguan pada mata yang mempengaruhi penglihatan sehingga menyebabkan penglihatan menjadi kabur. Penurunan ketajaman penglihatan dapat terjadi pada sebagian besar pasien DM, hal ini merupakan ancaman besar bagi penderita DM karena dapat menyebabkan retinopati diabetic bahkan kebutaan. Tujuan study literature ini disusun untuk menyajikan hubungan hipertensi dengan ketajaman penglihatan pada penderita DM Tipe 2. Penelusuran literature ini dilakukan untuk mendapatkan artikel yang sesuai dengan topik melalui database Google Scholar dengan menggunakan kata kunci atau Keyword pencarian Hypertension with visual acuity in diabetes "OR" hypertension with diabetic retinopathy "AND" healing.. Hasilnya didapatkan 17 artikel, yang memenuhi kriteria sebanyak 7 artikel yang sesuai dan melalui peninjauan diketahui terdapat hubungan hipertensi dengan ketajaman penglihatan pada penderita diabetes mellitus tipe 2. Faktor resiko yang mempengaruhi penglihatan dapat pula disebabkan karena faktor usia, jenis kelamin, lama menderita DM dan komplikasi lain pada penderita DM. Berdasarkan hasil telaah literatur dan dokumen terkait Hubungan Hipertensi dengan ketajaman Penglihatan pada penderita Diabetes Mellitus tipe 2. Terdapat hubungan hipertensi dengan penurunan ketajaman penglihatan. Disarankan kepada peneliti selanjutnya diharapkan mampu memperhatikan variabel lain yang berkontribusi menurunkan ketajaman penglihatan.

Kata Kunci : Hipertensi, ketajaman penglihatan, diabetes mellitus

\section{PENDAHULUAN}

Hipertensi adalah manifestasi gangguan keseimbangan hemodinamik system kardiovaskular. Hipertensi dapat menimbulkan kerusakan pada organ tubuh, baik secara langsung maupun tidak langsung. Pada pasien hipertensi ditemukan kerusakan organ yang secara umum ditemukan adalah penyakit jantung (hipertropi ventrikel kiri, infark miokardium, gagal jantung), otak (stroke, demensia), penyakit ginjal kronik, penyakit arteri perifer dan retinopati. (Yastina \& Afriant, 2017)
Hipertensi yang berkepanjangan dapat menyebabkan kerusakan pada bagian dalam arteri pada area mata dan beresiko terjadinya pembekuan darah. Jika hal ini terjadi pada mata dapat menyebabkan terjadinya retinopati hingga yang menyebabkan kaburnya pengihatan, penurunan ketajaman penglihatan bahkan sampai kebutaan. (Y. N. I. Sari, 2017) ?

Data World Health Organization (WHO) tercatat di Indonesia sekitar 3,5 Juta orang 
mengalami kebutaan akibat katarak pada tahun 2012. Menurut Pusat Data dan Informasi Kementerian Kesehatan RI tahun 2014, secara global penyebab gangguan penglihatan posisi pertama adalah gangguan retraksi dan gangguan katarak pada posisi ke-2 (33\%) Penyebab kebutaan. (Syawal et al., 2019)

Badan Penelitian dan Pengembangan Kesehatan (LITBANGKES) Kementrian Kesehatan RI mensurvei di 15 provinsi 2014-2016. Prevalensi kebutaan di Indonesia berkisar antaran 1,7\% sampai dengan 4,4\%. Prevalensi kebutaan di Indonesia adalah 3,0\%. Data terakhir dari Hasil Survei RAAB (Rapid Assesment of Avoidable Blindness) tahun 2014 prevalensi angka kebutaan di Sulawesi Selatan sebanyak $2,6 \%$ dan prevalensi katarak sebanyak $64,3 \%$. RAAB adalah pengumpulan data yang mengalami gangguan penglihatan dan kebutaan berstandar yang sudah ditetapkan oleh WHO, melalui Global Action Plan (GAP) 2014-2019. (KEMENKES RI, 2018)

Diabetes merupakan penyebab kebutaan pada dewasa usia 20-74 tahun. Pada tahun 2008, sekitar 3,6 juta dewasa dengan diabetes dilaporkan memiliki gangguan penglihatan yan diartikan sebagai kesulitan melihat atau penurunan ketajaman penglihatan. Jumlah individu dengan penyakit mata sehubungan dengan Diabetes juga akan meningkat, Antara 2005 hingga 2050 diperkirakan retinopati diabetik akan meningkat tiga kali hingga mencapai 16 juta dari 5,5 juta orang. (Kurniawan, 2018)

(FK UI, 2014). Semakin tinggi pengaruh gangguan penyakit yang diderita pasien maka semakin rendah kualits hidup seseorang, karena gangguan penglihatan dan penyakit mata berdampak terhadap kualitas hidup pasien. Untuk itu perlu dilakukan deteksi ketajaman penglihatan pada pasien Diabetes Mellitus terutama yang memiliki riwayat Hipertensi. Pasien DM Type 2 yang mengalami hipertensi sangat beresiko mengalami penurunan ketajaman penglihatan dibanding dengan pasien diabetes yang mempunyai tekanan darah yang terkontrol. Penurunan Ketajaman Penglihatan terjadi karena dengan hipertensi akan merusak vaskuler pembuluh darah pada retina sehingga menyebabkan gangguan sirkulasi yang menghalangi aliran darah ke retina.

Penelitian yang dilakukan oleh (Anindita, 2010) yang memiliki jumlah responden sebanyak 83 orang, dengan deskriptif analitik dan pendekatan cross sectional. Dari 83 diketahui pasien diabetes melitus dengan hipertensi memiliki risiko untuk mengalami retinopati sebelas kali lebih besar daripada tanpa hipertensi dan peningkatan risiko tersebut secara statistik signifikan (OR $=11.2 ; \mathrm{Cl}$ 95\% 2.7 sampai dengan 46.6)

Berdasarkan fenomena yang terjadi ini dapat disimpulkan bahwa hipertensi sangat erat kaitannya dengan penglihatan khususnya ketajaman penglihatan pada penderita diabetes mellitus. Tujuan study literature ini disusun untuk menyajikan hubungan hipertensi dengan ketajaman penglihatan pada penderita DM Tipe 2.

\section{METODE}

Pengambilan data dilakukan melalui studi pustaka/literatur dengan cara melakukan penelusuran hasil publikasi ilmiah dengan rentang tahun 2010-2020 dengan menggunakan database Google Scholar. Hasil penelusuran dianalisis dan disimpulkan.

\section{HASIL}

Hasil Studi Literatur ini melalui penelusuran hasil publikasi ilmiah baik jurnal, buku maupun dokumen skripsi yang dipublikasikan dengan rentang tahun 2010-2020 dengan menggunakan database Google Scholar. Pada database Google Scholar menggunakan keyword Hypertension with visual acuity in diabetes "OR" hypertension with diabetic retinopathy "AND" Assessment "AND" Valid "OR" Reliable "AND" healing.Pada pencarian Google Scholar dilakukan skrining tahun (2010-2020) dan menggunakan frase "Hypertension with visual acuity in diabetes".

Berdasarkan hasil pencarian literatur pada Google Scholar didapatkan 17 literatur ilmiah meliputi artikel, jurnal dan naskah publikasi ilmiah, terdapat 7 artikel yang memenuhi kriteria inklusi dan relevan dengan variabel Hipertensi dengan ketajaman penglihatan pada penderita diabetes mellitus tipe 2 .

$$
\text { Penelitian -penelitian tersebut }
$$

mengidentifikasikan bagaimana hubungan hipertensi dengan gangguan penglihatan pada penderita diabetes mellitus.

Tabel 1. Sintesis Grid

\begin{tabular}{|c|c|c|c|c|c|c|}
\hline $\begin{array}{l}N \\
0\end{array}$ & Peneliti & $\begin{array}{c}\text { Tujuan } \\
\text { penelitian }\end{array}$ & $\begin{array}{c}\text { Desain } \\
\text { penelitian }\end{array}$ & Responden & $\begin{array}{c}\text { Pengumpulan } \\
\text { data }\end{array}$ & Hasil penelitian \\
\hline 1 & $\begin{array}{l}\text { Rahmawati, } \\
\text { Amiruddin (2017) } \\
\text { Glycohemogl obin, } \\
\text { Hipertensi, IMT } \\
\text { terhadap gangguan } \\
\text { penglihatan penderita }\end{array}$ & $\begin{array}{l}\text { Untuk } \\
\text { mengetahui } \\
\text { hubungan } \\
\text { Glycohemo } \\
\text { glo bin, } \\
\text { Hipertensi. }\end{array}$ & $\begin{array}{l}\text { Cross } \\
\text { sectional } \\
\text { study. }\end{array}$ & $\begin{array}{l}\text { Responde } n \\
\text { pada } \\
\text { penelitian ini } \\
\text { sebanyak } 26 \\
\text { orang. }\end{array}$ & $\begin{array}{l}\text { Data demografi } \\
\text { dikumpulkan : } \\
\text { umur, jenis } \\
\text { kelamin, } \\
\text { pendidikan dan } \\
\text { dilakukan }\end{array}$ & $\begin{array}{l}\text { Hasil penelitian menunjukan } \\
\text { bahwa } \\
\text { Berdasarkan hasil uji } \\
\text { spearman didapatkan nilai } \\
\text { korelasi spearman }=0.094 \\
\text { dan nilai } p=0.649 \text {. Hal ini }\end{array}$ \\
\hline
\end{tabular}




\begin{tabular}{|c|c|c|c|c|c|c|}
\hline & diabetes Mellitus & $\begin{array}{l}\text { IMT } \\
\text { terhadap } \\
\text { gangguan } \\
\text { penglihatan } \\
\text { penderita } \\
\text { diabetes } \\
\text { mellitus. }\end{array}$ & & & $\begin{array}{l}\text { pengukuran } \\
\text { HbA1c, } \\
\text { Pemeriksaan } \\
\text { tekanan darah } \\
\text { dengan } \\
\text { menggunakan } \\
\text { tensi air raksa, } \\
\text { IMT dilakukan } \\
\text { pengukuran } \\
\text { dengan } \\
\text { menggunakan } \\
\text { timbangan dan } \\
\text { meteran. } \\
\text { Karakteristik } \\
\text { gangguan } \\
\text { penglihatan } \\
\text { diketahui dengan } \\
\text { menggunakan } \\
\text { kuesioner yang } \\
\text { diklasifikasikan } \\
\text { menjadi } 3 \text { yaitu } \\
\text { penglihatan } \\
\text { normal, gangguan } \\
\text { penglihatan dan } \\
\text { ringan, } \\
\text { gangguan dan } \\
\text { penglihatanberat }\end{array}$ & $\begin{array}{l}\text { berarti bahwa tidak ada } \\
\text { hubungan antara HbA1c } \\
\text { dengan gangguan } \\
\text { penglihatan pada penderita } \\
\text { Diabetes Mellitus lansia } \\
\text { Berdasarkan hasil uji } \\
\text { spearman didapatkan nilai } \\
\text { korelasi spearman }=0.669 \\
\text { dan nilai } p=0.000 \text {. Hal ini } \\
\text { berarti ada hubungan } \\
\text { secara positif antara } \\
\text { hipertensi dengan gangguan } \\
\text { penglihatan pada penderita } \\
\text { diabetes mellitus lansia } \\
\text { dengan kekuatan korelasi } \\
\text { sedang has uji } \\
\text { Berdasarkan hasil uil } \\
\text { spearman didapatkan nilai } \\
\text { korelasi spearman =-.327 } \\
\text { dan } p=0.103 \text {. Hal ini berarti } \\
\text { tidak ada hubungan antara } \\
\text { Indeks Massa Tubuh } \\
\text { dengan gangguan } \\
\text { penglihatan pada penderita } \\
\text { diabetes mellitus lansia }\end{array}$ \\
\hline 2 & $\begin{array}{l}\text { Yunia Annisa, } \\
\text { M.Fadhol } \\
\text { Romdhoni., } \\
\text { (2017)., } \\
\text { PerbandinganResiko } \\
\text { Terjadinya } \\
\text { Retinopati Diabetik } \\
\text { Antara Pasien } \\
\text { Hipertensi Dan Non } \\
\text { Hipertensi yang } \\
\text { Mengidap Diabetes } \\
\text { Mellitus Di RSUD } \\
\text { Majenang }\end{array}$ & $\begin{array}{l}\text { Untuk } \\
\text { mengetahui } \\
\text { perbanding } \\
\text { an resiko } \\
\text { terjadinya } \\
\text { retiopati } \\
\text { diabetik } \\
\text { antara } \\
\text { pasien } \\
\text { hipertensi } \\
\text { dan non } \\
\text { hipertensi } \\
\text { yang } \\
\text { mengidap } \\
\text { diabetes } \\
\text { mellitus di } \\
\text { RSUD } \\
\text { Majenan } \\
\mathrm{g}\end{array}$ & $\begin{array}{l}\text { Cross } \\
\text { Section } \\
\text { al }\end{array}$ & $\begin{array}{l}\text { Responden } \\
\text { pada } \\
\text { penelitianini } \\
\text { sebanyak } 90 \\
\text { responden }\end{array}$ & $\begin{array}{l}\text { Data demografi } \\
\text { dikumpulkan : } \\
\text { umur dan jenis } \\
\text { kelamin. data } \\
\text { tentang hipertensi } \\
\text { atau tekanan } \\
\text { darah dan } \\
\text { retinopati diabetic } \\
\text { didapatkan pada } \\
\text { rekam medis } \\
\text { responden. }\end{array}$ & $\begin{array}{l}\text { Berdasarkan hasil penelitian } \\
\text { menunjukan bahwa } 90 \\
\text { responden yangmengalami } \\
\text { hipertensi disertai dengan } \\
\text { retinopati sebanyak } 15 \\
\text { orang (16,67\%),yang } \\
\text { mengalami hipertensi dan } \\
\text { tidak mengalami retinopati } \\
\text { sebanyak } 20 \text { responden } \\
\text { (22,23). Pada responden } \\
\text { yang non hipertensi dan } \\
\text { mengalami retinopati } \\
\text { sebanyak } 7 \text { responden } \\
(7,78 \%) \text {, dan yang tidak } \\
\text { mengalami hipertensi serta } \\
\text { tidak mengalami retinopati } \\
\text { sebanyak 48 responden } \\
(53,33 \%) \text {. } \\
\text { Perbandingan pasien } \\
\text { diabetes mellitus dengan } \\
\text { hipertensi memiliki resiko } \\
\text { mengalami retinopati } 12 \text { kali } \\
\text { lebih besar daripada non } \\
\text { hipertensi danpeningkatan } \\
\text { resiko tersebut secara } \\
\text { statistik signifikan (OR } \\
=12,3 ; 95 \% \mathrm{Cl} \\
=3,7-56,5) \text {. }\end{array}$ \\
\hline 3 & $\begin{array}{l}\text { Ils Noventi,dkk., } \\
\text { (2018) } \\
\text { Faktor Resiko } \\
\text { Retinopati } \\
\text { Diabetika: ACase } \\
\text { - Control }\end{array}$ & $\begin{array}{l}\text { Tujuan } \\
\text { penelitian } \\
\text { menentukan } \\
\text { faktor-factor } \\
\text { resiko } \\
\text { pengembang } \\
\text { an DR di } \\
\text { RSMM } \\
\text { Jawa }\end{array}$ & $\begin{array}{l}\text { studi } \\
\text { kasus- } \\
\text { kontrol }\end{array}$ & $\begin{array}{l}\text { Responden } \\
\text { sebanyak60 } \\
\text { responden } \\
\text { yang } \\
\text { berhubungan } \\
\text { dengan } \\
\text { retinopati } \\
\text { diabetic DR } \\
\text { NPDR Dan }\end{array}$ & $\begin{array}{l}\text { Data dikumpulkan } \\
\text { menggunakan } \\
\text { kuesioner } \\
\text { termasuk: data } \\
\text { demografi (jenis } \\
\text { kelamin dan usia), } \\
\text { GDA, profil DM } \\
\text { (Durasi diabetes) } \\
\text { dan komorbiditas }\end{array}$ & $\begin{array}{l}\text { Hasil menunjukkan DR } \\
\text { NPDR pasien perempuan } \\
\text { dominan }(60 \%) \text {, pada PDR } \\
\text { pasien laki-laki } \\
\text { dominan(60\%). DR NPDR } \\
\text { pasien dengan tidak } \\
\text { mempunyai hipertensi } \\
\text { dominan (53,3\%), pada } \\
\text { PDR pasien dengan }\end{array}$ \\
\hline
\end{tabular}




\begin{tabular}{|c|c|c|c|c|c|c|}
\hline & & $\begin{array}{l}\text { Timur } \\
\text { Surabaya }\end{array}$ & & $\begin{array}{l}\text { DRPDR } \\
\text { Masing- } \\
\text { masing } 30 \\
\text { responden(30 } \\
\text { kasus } \\
\text { dan } 30 \\
\text { kontrol) }\end{array}$ & 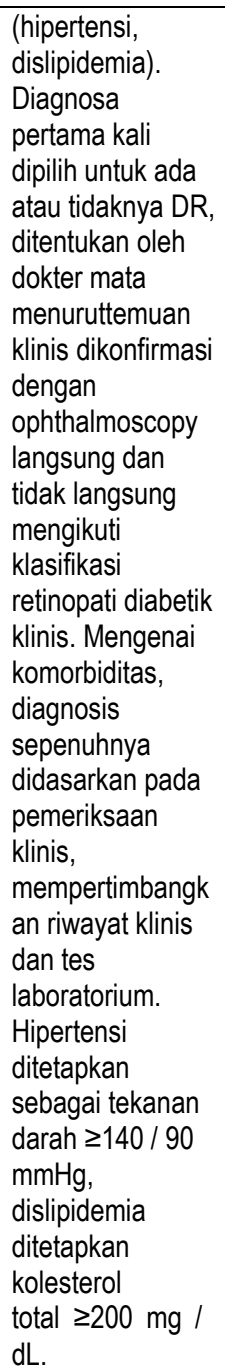 & $\begin{array}{l}\text { hipertensi dominan (73,3\%). } \\
\text { DR NPDR pasien dengan } \\
\text { dislipidemia dominan (60\%), } \\
\text { pada PDRpasien dengan } \\
\text { dislipidemia dominan } \\
\text { (63,3\%). Umur terendah } \\
\text { pasien DR NPDR ditemukan } \\
\text { adalah } 39 \text { tahun, dan } \\
\text { tertinggi } 82 \text { tahun. Pada } \\
\text { PDR umur terendah adalah } \\
40 \text { tahun dan umur tertinggi } \\
\text { adalah } 63 \text { tahun. Gula darah } \\
\text { terendah pada pasien } \\
\text { NPDR adalah } 94 \text { mg/dl, dan } \\
\text { tertinggi } 571 \text { mg/dl. Pada } \\
\text { PDR gula darah terendah } \\
\text { adalah } 108 \text { mg/dl, dan } \\
\text { tertinggi } 453 \text { mg/dl. Lama } \\
\text { menderita DM terendah } \\
\text { pada NPDR adalah } 1 \\
\text { tahun,dan terlama } 50 \text { tahun. } \\
\text { Pada PDR terendah } 1 \text { tahun } \\
\text { dan terlama20 tahun. } \\
\text { Dengan demikian pasien } \\
\text { diabetes perempuan, } \\
\text { dengan dislipidemia, umur }> \\
30 \text { s.d }<85 \text { tahun, dengan } \\
\text { lama menderita } 1 \mathrm{~s} . \mathrm{d} \leq 50 \\
\text { tahun mempunyai resiko } \\
\text { NPDR. Sedangkan pasien } \\
\text { diabetes laki-laki, hipertensi } \\
\text { dan dislipidemia, umur } \geq 40 \\
\text { s.d <65 tahun, dengan lama } \\
\text { menderita } 1 \text { s.d } \leq 20 \text { tahun } \\
\text { mempunyai resiko PDR. }\end{array}$ \\
\hline 4 & $\begin{array}{l}\text { Dewi dkk.,(2019)., } \\
\text { Profil Tingkat } \\
\text { Keparahan Retinopati } \\
\text { Diabetik Dengan Atau } \\
\text { Tanpa Hipertensi } \\
\text { pada di RSUP Dr. M. } \\
\text { Djamil Padang }\end{array}$ & $\begin{array}{l}\text { Tujuan } \\
\text { penelitian } \\
\text { ini adalah } \\
\text { mengetahui } \\
\text { profil } \\
\text { tingkat } \\
\text { keparahan } \\
\text { retinopati } \\
\text { diabetik } \\
\text { dengan } \\
\text { atau tanpa } \\
\text { hipertensi } \\
\text { padapasien } \\
\text { diabetes } \\
\text { melitus di } \\
\text { RSUP Dr. } \\
\text { M. Djamil } \\
\text { Padang }\end{array}$ & $\begin{array}{l}\text { Deskriptif } \\
\text { observasi } \\
\text { onal }\end{array}$ & $\begin{array}{l}\text { Responden } \\
\text { sebanyak } \\
162 \text { orang } \\
\text { dengan } \\
\text { Kriteria } \\
\text { inklusi adalah } \\
\text { responden } \\
\text { dengan } \\
\text { retinopati } \\
\text { diabetik } \\
\text { dengan hasil } \\
\text { pemeriksaan } \\
\text { tekanandarah } \\
\text { lengkap yang } \\
\text { terdapat } \\
\text { dalam rekam } \\
\text { medik RSUP } \\
\text { Dr. M. Djamil } \\
\text { Padang } \\
\text { antara bulan } \\
\text { 1-12 2016. }\end{array}$ & $\begin{array}{l}\text { Data yang } \\
\text { dikumpulkanyaitu } \\
\text { umur, jenis } \\
\text { kelamin, durasi } \\
\text { menderita DM, } \\
\text { tekanan darah, } \\
\text { Disiplidemia, } \\
\text { retinopati diabetik } \\
\text { tentang tingkatan } \\
\text { keparahan } \\
\text { retinopati yang } \\
\text { dialami } \\
\text { responden,data } \\
\text { ini diperoleh dari } \\
\text { rekam medik } \\
\text { responden. }\end{array}$ & $\begin{array}{l}\text { Hasil penelitian ini } \\
\text { menunjukan pasien } \\
\text { retinopati diabetik dengan } \\
\text { hipertensi sebanyak } 102 \\
\text { orang }(62,9 \%) \text {. Sementara } \\
\text { itu, pasien yang tidak } \\
\text { menderita hipertensi } \\
\text { sebanyak } 60 \text { orang ( } 37,1 \%) \text {. } \\
\text { Pada pasien dengan } \\
\text { hipertensi ditemukan tingkat } \\
\text { keparahan retinopati } \\
\text { diabetik yang berbeda- } \\
\text { beda,yaitumild NPDR } \\
\text { sebesar } 58,1 \% \text {, moderate } \\
\text { NPDR sebesar } 60,5 \% \text {, } \\
\text { severe NPDR sebesar } 60 \% \\
\text { dan PDR sebesar } 69,6 \% \text {, } \\
\text { sedangkan untuk pasien } \\
\text { retinopati diabetik tanpa } \\
\text { hipertensi ditemukantingkat } \\
\text { keparahan retinopati } \\
\text { diabetik dengan persentase } \\
\text { yang lebih kecil yaitu mild } \\
\text { NPDR sebesar } 41,9 \% \text {, } \\
\text { moderate NPDR sebesar } \\
39,5 \% \text {, severeNPDR }\end{array}$ \\
\hline
\end{tabular}




\begin{tabular}{|c|c|c|c|c|c|c|}
\hline & & & & & & $\begin{array}{l}\text { sebesar } 40 \% \text {, dan PDR } \\
\text { sebesar } 30,4 \% \text {. }\end{array}$ \\
\hline 5 & $\begin{array}{l}\text { Dyah RahayuUtami } \\
\text { dkk., (2017) } \\
\text { KarakteristikKlinis } \\
\text { PasienRetinopati } \\
\text { Diabetik Periode } 1 \\
\text { Januari 2014-31 } \\
\text { Desember2015 di } \\
\text { RSUP Dr. } \\
\text { Mohammad Hoesin } \\
\text { Palembang }\end{array}$ & $\begin{array}{l}\text { Penelitian ini } \\
\text { bertujuan } \\
\text { untuk } \\
\text { mengetahui } \\
\text { karakteristik } \\
\text { pasien } \\
\text { retinopati } \\
\text { diabetik di } \\
\text { RSUP Dr. } \\
\text { Mohammad } \\
\text { Hoesin } \\
\text { Palembang }\end{array}$ & $\begin{array}{l}\text { deskripti f } \\
\text { observasi } \\
\text { onal }\end{array}$ & $\begin{array}{l}\text { Responden } \\
\text { sebanyak75 } \\
\text { orang dengan } \\
\text { kriteria } \\
\text { inkluasi } \\
\text { pasien } \\
\text { diabetes } \\
\text { mellitus yang } \\
\text { di diagnose } \\
\text { retinopati } \\
\text { diabetic }\end{array}$ & $\begin{array}{l}\text { Data demografi } \\
\text { dikumpulkan : } \\
\text { usia, jeniskelamin, } \\
\text { tekanan darah, } \\
\text { GDS,HbA1c, } \\
\text { Total kolesterol, } \\
\text { HDL, LDL, Dan } \\
\text { trigliserid }\end{array}$ & $\begin{array}{l}\text { Hasil penelitian ini tentang } \\
\text { karakteristikklinis pasien } \\
\text { retinopati Dari } 75 \text { pasien } \\
\text { yang diteliti, didapatkan } \\
\text { paling banyak ( } 82.7 \% \text { ) pada } \\
\text { kelompok usia } 45-64 \text { tahun. } \\
\text { Mayoritas adalah } \\
\text { perempuan (64\%). Distribusi } \\
\text { retinopati diabetik } \\
\text { berdasarkan tekanan darah } \\
\text { terbanyak adalah } \\
\text { prehipertensi (33.3\%).Dari } \\
70 \text { pasien, mayoritas adalah } \\
\text { (58.7\%) dengan kadar GDS } \\
\geq 200 \text { gr/dl.Dari } 34 \text { pasien } \\
\text { yang data HbA1c ada, yang } \\
\text { paling banyak (25.3\%) } \\
\text { memiliki kadar }>8 \% \text {. Dari } 43 \\
\text { pasien retinopati diabetik } \\
\text { berdasarkan kadar total } \\
\text { kolesterol terbanyak } \\
\text { (30.7\%) dengan kadar } \\
\geq 240 \text {. Pasien retinopati } \\
\text { diabetik paling banyak } \\
(16 \%) \text { memilikiLDL } \\
>190 \text {. }\end{array}$ \\
\hline 6 & $\begin{array}{l}\text { Rusman Shiddiq dkk., } \\
\text { (2011). } \\
\text { Hubungan Hipertensi } \\
\text { dan Glycohemoglobin } \\
\text { (HbA1c)dengan } \\
\text { Kejadian Retinopati } \\
\text { Diabetika Pada } \\
\text { Penderita Diabetes } \\
\text { Mellitus diRSUD Di } \\
\text { Margono Soekarno } \\
\text { Purwokerto }\end{array}$ & $\begin{array}{l}\text { Untuk } \\
\text { Mengetahui } \\
\text { Hubungan } \\
\text { Hipertensi } \\
\text { dan } \\
\text { Glycohemo } \\
\text { globin } \\
\text { (HbA1c) } \\
\text { dengan } \\
\text { Kejadian } \\
\text { Retinopati } \\
\text { Diabetika } \\
\text { Pada } \\
\text { Penderita } \\
\text { Diabetes } \\
\text { Mellitus di } \\
\text { RSUD Di } \\
\text { Margono } \\
\text { Soekarno } \\
\text { Purwokerto }\end{array}$ & $\begin{array}{l}\text { Cross } \\
\text { Sectional }\end{array}$ & $\begin{array}{l}\text { Responde } n \\
\text { sebanyak } 35 \\
\text { orang dengan } \\
\text { kriteria inklusi } \\
\text { pasien DM } \\
\text { Yang berusia } \\
\geq 40 \text { thn dan } \\
\text { terdiagnosis } \\
\text { Diabetes } \\
\text { Mellitus Tipe } \\
2 \geq 5 \text { thn di } \\
\text { poliklinik DM } \\
\text { RSUD Prif. } \\
\text { Dr. Margono } \\
\text { Soekarjo }\end{array}$ & $\begin{array}{l}\text { Data demografi } \\
\text { dikumpulkan : } \\
\text { umur, jenis } \\
\text { kelamin, } \\
\text { pengukuran } \\
\text { HbA1c untuk } \\
\text { mengetahui kadar } \\
\text { glukosa, } \\
\text { pengukuran } \\
\text { tekanan darah } \\
\text { dan pemeriksaan } \\
\text { fundoskopi } \\
\text { yang dilakukan } \\
\text { oleh dokter } \\
\text { spesialis penyakit } \\
\text { mata untuk } \\
\text { mengetahui } \\
\text { apakah } \\
\text { responden } \\
\text { mengalami } \\
\text { retinopati diabetik. }\end{array}$ & $\begin{array}{l}\text { Kelompok sampel mayoritas } \\
\text { orang berjenis kelamin } \\
\text { perempuan ( } \mathrm{n}=18 \text { ) Berusia } \\
>59 \text { tahun, lama menderita } \\
\text { DM5-9 tahun, menderita } \\
\text { hipertensi, dan memiliki } \\
\mathrm{HbA} 1 \mathrm{c} \geq 7 \% \text {. menunjukkan } \\
\text { bahwa data terbanyak yaitu } \\
16 \text { responden dari seluruh } \\
\text { sampel penelitian } \\
\text { mengalami hipertensi dan } \\
\text { retinopati diabetic. } \\
\text { Sedangkan sebagian besar } \\
\text { responden yang mengalami } \\
\text { komplikasi retinopati } \\
\text { diabetik memiliki kadar } \\
\text { HbA1c } \geq 7 \% \text { yaitu sebanyak } \\
16 \text { orang, } \\
\text { Selain itu, responden yang } \\
\text { tidak mengalami retinopati } \\
\text { diabetik paling banyak } \\
\text { berada pada HbA1c } \geq 7 \% \\
\text { yaitusebanyak } 15 \text { orang }\end{array}$ \\
\hline 7 & $\begin{array}{l}\text { Hamzatun Syawal } \\
\text { dkk., (2019) Faktor } \\
\text { Yang Berhubungan } \\
\text { Dengan Ketajaman } \\
\text { Penglihatan Pasien } \\
\text { Diabetes Melitus Tipe } \\
2 \text { Di Wilayah Kerja } \\
\text { Puskemas Kecamatan } \\
\text { BiringkanayaKota } \\
\text { Makassar }\end{array}$ & $\begin{array}{l}\text { Untuk } \\
\text { mengetahu } \\
\text { i hubungan } \\
\text { faktor yang } \\
\text { mempenga } \\
\text { ruhi } \\
\text { ketajaman } \\
\text { penglihatan } \\
\text { pasien } \\
\text { diabetes } \\
\text { melitus tipe } \\
2 \text { di wilayah } \\
\text { kerja }\end{array}$ & $\begin{array}{l}\text { Cross } \\
\text { Sectional }\end{array}$ & $\begin{array}{l}\text { Responde } n \\
\text { sebanyak } 45 \\
\text { orang } \\
\text { diabetes di } \\
\text { wilayah kerja } \\
\text { puskemsmas } \\
\text { kecematan } \\
\text { Biringkan } \\
\text { aya. }\end{array}$ & $\begin{array}{l}\text { Data demografi } \\
\text { dikumpulkan : } \\
\text { usia, jenis } \\
\text { kelamin, lama } \\
\text { menderitaDM, } \\
\text { komplikasi DM, } \\
\text { Kadar Gula darah. } \\
\text { Untukmegetahui } \\
\text { ketajaman } \\
\text { penglihatan } \\
\text { dilakukan } \\
\text { pengukuran } \\
\text { dengan }\end{array}$ & $\begin{array}{l}\text { Hasil analisis ada hubungan } \\
\text { yang signifikan antara kadar } \\
\text { glukosa darahpasien } \\
\text { Diabetes Melitus dengan } \\
\text { penurunan ketajaman } \\
\text { penglihatan dengan nilai } P= \\
0,003(P<0,050) \text {. } \\
\text { Hasil analisis adanya } \\
\text { hubungan faktor usia } \\
\text { dengan penurunan } \\
\text { ketajaman penglihatan } P \\
\text { Value }=0,015 \text { dengan nilai } \\
\text { OR } 13,2 \text {. Hasil uanalisis }\end{array}$ \\
\hline
\end{tabular}




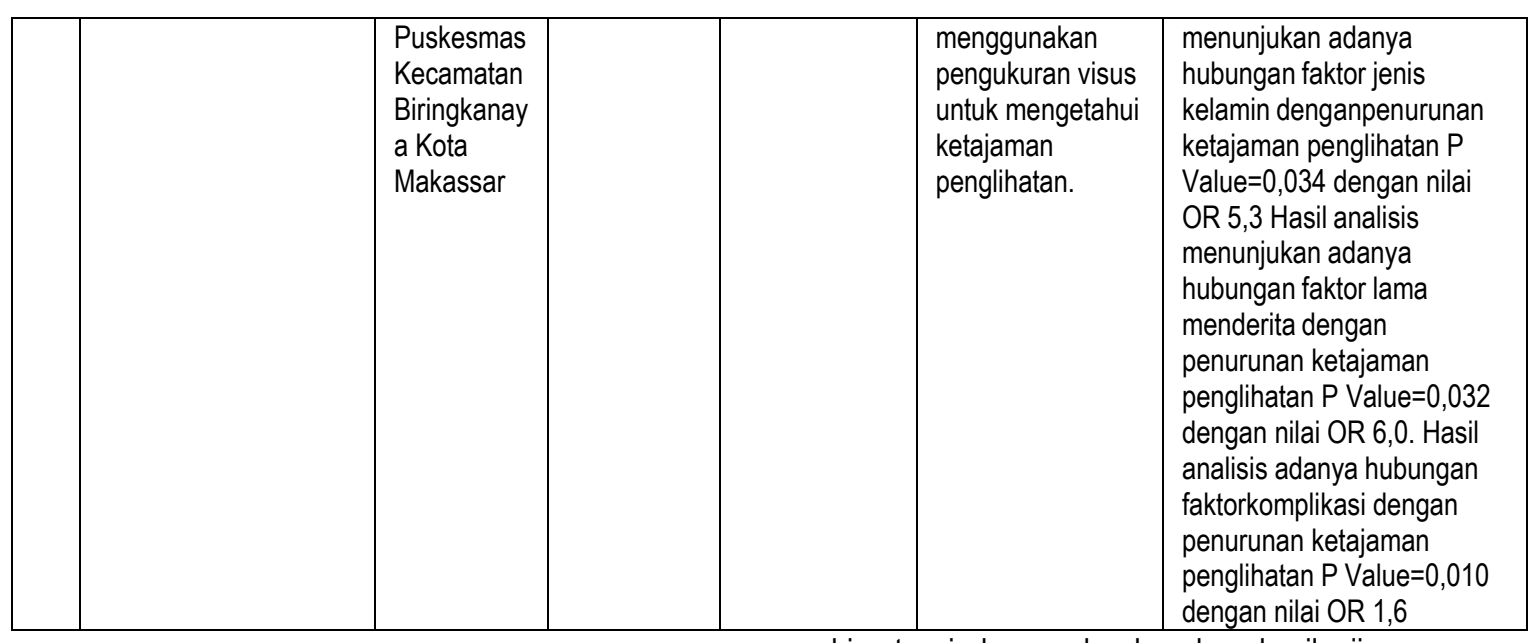

\section{PEMBAHASAN}

Hipertensi merupakan salah satu faktor resiko yang penting dalam gangguan penglihatan pada penderita diabetes mellitus, tekanan darah tinggi yang berkepanjangan pada penderita Diabetes Mellitus menyebabkan perubahan pada mikrovaskuler yang mengakibatkan kerusakan sell endotel pembuluh darah di retina. (Kurniawan, 2018).

Retinopati diabetik adalah suatu kelainan retina karena perubahan pembuluh darah retina akibat diabetes sehingga mengakibatkan gangguan nutrisi pada retina (Ina DRS, 2013). (Yunia \& Romdhoni, 2017). Kelainan pada mata merupakan kelaianan mata yang dapat mempengaruhi penglihatan sehingga menyebabkan ketajaman pengihatan menurun dan penglihatan menjadi kabur bahkan dapat menyebabkan kebutaan. Hasil temuan artikel pada penelitian yang dilakukan oleh (Rahmawati \& Amiruddin, 2017) yang menganalisa tentang hubungan glycohemoglobin, hipertensi, IMT terhadap gangguan penglihatan pada penderita diabetes mellitus pada lansia dengan desain penelitian analitik observasional dengan jumlah sampel sebanyak 26 responden yang merupakan pasien penderita diabetes mellitus yang berobat di Puskemsmas WuaWua. Pengumpulan data menggunakan koesioner dan pemeriksaan responden. terkhusus untuk variabel gangguan penglihatan menggunakan teknik pengambilan data menggunakan koesioner pada pasien lansia yang diklasifikasikan Normal, Ringan dan Berat menurut peneliti hal ini dianggap kurang efektif dalam mendeskripsikan tentang kondisi gangguan penglihatan pada pasien diabetes mellitus jika hanya dengan memberikan kuesioner tanpa adanya pemeriksaan pada mata, sebaiknya pengambilan datanya dilakukan dengan pemeriksaan atau pengukuran secara langsung pasien diabetes mellitus pada lansia. Peneliti lebih lanjut menyebutkan tidak adanya hubungan $\mathrm{HbA} 1 \mathrm{c}$ dan IMT dengan gangguan penglihatan pada penderita Diabetes mellitus lansia, dan hasil penelitian variabel hipertensi dengan berdasarkan hasil uji spearman dengan nilai korelasi spearman $=0,669$ dan nilai $p=0,000$ yang menandakan arah korelasi positif dengan kekutan korelasi sedang. Hal ini menunjukan adanya hubungan antara hipertensi dengan gangguan pengihatan pada penderita diabetes mellitus lansia. (Rahmawati \& Amiruddin, 2017) mengambil kesimpulan para penderita diabetes mellitus agar tetap melakukan pengendalian diabetes mellitus dengan cara pola hidup sehat, mempertahankan pola hidup ideal dengan menjaga pola makan serta selalu mengontrol tekanan darah secara teratur.

Penelitian yang dilakukan oleh (Shiddiq et al., 2011) menjelaskan tentang hubungan Hipertensi, Glycohemoglobin dengan kejadian retinopati diabetic pada penderita diabetes mellitus, penelitian ini berfokus pada pentinya pengendalian tekanan darah dan glycohemoglobin yang dapat mengurangi resiko terjadinya diabetik retinopati dengan desain penelitian analitik observasional dengan menggunakan pendekatan Cross Sectional, besar sampel yang telah dipilih melalui kriteria inklusi dan eksklusi berjumlah 35 orang yang merupakan pasien diabetes mellitus tipe 2 yang berusia $\geq 40$ tahun dan lama menderita $\geq 5$ tahun di poliklinik penyakit dalam RSUD Prof. dr. Margono Soekarjo. Penelitian ini kurang mendeskripsikan tentang kriteria inklusi dan eksklusi.

Penelitian (Shiddiq et al., 2011) mengemukakan bahwa hasil analisis hubungan hipertensi dengan retinopati diabetik menunjukkan nilai $X^{2}=7,098$ dan $P=0,008$. Nilai $P$ pada penelitian ini kurang dari 0,05 , sehingga menunjukan bahwa terdapat hubungan yang bermakna antara hipertensi dengan kejadian retinopati diabetik, hasil analisis hubungan $\mathrm{HbA} 1 \mathrm{C}$ dengan retinopati diabetik menunjukan nilai $P=1,00$ ini menandakan tidak ada hubungan yang bermakna antara $\mathrm{HbA} 1 \mathrm{c}$ dengan kejadian retinopati diabetik.

Penelitian yang dilakukan oleh (Yunia \& Romdhoni, 2017) menjelaskan tentang resiko 
terjadinya diabetic retinopati antara pasien hipertensi dan non hipertensi pasien Diabetes mellitus di RSUD Majenang dengan menggunakan metode penelitian deskriptif analitik dengan desain penelitian Cross sectional, sampel pada penelitian ini adalah pasien diabetes mellitus yang berjumlah 90 orang yang merupakan pasien di RSUD Majenang yang dilakukan dalam jangka waktu selama 5 bulan. Penelitian ini masih kurang dalam menyajikan informasi didalamnya mengenai kriteria inklusi dan eksklusi dari penelitian.

Pada penelitian Yunia \& Romdhoni, ,2017 menyebutkan pasien diabetes mellitus yang disertai dengan hipertensi lebih bersiko yang mengalami retinopati diabetik daripada pasien non hipertensi, dengan hasil statistic signifikan $(O R=12,3 ; 95 \% \mathrm{Cl}$ $=3,7-56,5$ ). Dari penelitian ini menandakan menandakan bahwa pasien diabetes dengan hipertensi beresiko mengalami retinopati diabetik 12 kali lebih besar dari pada non hipertensi.

Seseorang yang mengalami diabetes mellitus selama 3 tahun dan dimulai pada usia 45 tahun disarankan untuk melakukan pemeriksaan mata sebagai salah satu deteksi dini untuk mencegah terjadinya retinopati diabetik yang mengancam penglihatan, ketika karakteristik retinopati diketahui secara dini maka kontrol hiperglikemia dan tekanan darah dapat dilakukan dan memperlambat perkembangan retinopati diabetik yang dapat menyebabkan kebutaan. Peneliti senang tiasa meneliti dan terus mencari kelainan patologis pada retinopati diabetik sebagai bentuk penapisan retinopati diabetrik. Hal ini juga sering diteliti mempertanyakan karakteristik dari retinopati diabetic. Penelitian dari Dyah Rahayu Utami, 2017 yang dilakukan di Palembang, mencari tahu bagaimana karakteristik klinis apa saja yang terdapat pada pasien retinopati diabetik.

(Utami et al., 2017) menyebutkan karakteristik yang dialami pasien retinopati diabetic sebanyak 75 responden adalah kelompok umur 45-64 tahun, jenis kelamin perempuan, pasien hipertensi dengan kategori pre-hipertensi, kadar GDS $\geq 200 \mathrm{gr} / \mathrm{dl}$, $\mathrm{HbA} 1 \mathrm{c}>8 \%$, kadar kolesterol total $\geq 240 \mathrm{mg} / \mathrm{dl}$, HDL 41-59, LDL > 190 dan kadar trigliserida <150. Faktor yang paling banyak ditemui adalah perempuan dengan kelompok usia 45-64 tahun, pasien prehipertensi, kendali gula darah yang buruk, serta keadaan disipledemia. Perhatian utama dalam penelitian ini adalah retinopati diabetik terkadang tidak menimbulkan gejala sehingga sering terlambat didiagnosa hal ini menjadi salah satu hal penting untuk diwaspadai karena akan menimbulkan kebutaan. Pengumpulan data dilakukan dengan mengobsevasi rekam medik pasien diabetes mellitus yang didiagnosa retinopati diabetik.

(Utami et al., 2017) lebih lanjut menjelaskan bahwa faktor yang paling banyak ditemui adalah perempuan dengan kelompok usia 45-64 tahun, pasien prehipertensi, kendali gula darah yang buruk, serta keadaan disipledemia. Secara khusus hasil penelitian didapatkan tekanan darah yang terbanyak mengalami prehipertensi yaitu sebanyak 33,3\%, hipertensi stadium I dan II berturut-turut $30,7 \%$ dan $29,3 \%$ serta hanya $6,7 \%$ saja yang memiliki tekanan darah normal. Hal ini menandakan antara prehipertensi dan keadaan hipertensi tidak jauh berbeda, antara grade I dan II.

Pasien diabetes mellitus dengan kontrol tekanan darah yang tidak adekuat akan meningkatkan resiko komplikasi mikrovaskuler, meningkatkan resiko yang memperburuk fungsi penglihatan dan meningkatkan resiko progresifitas retinopati diabetik dibanding dengan pasien diabetes mellitus dengan tekanan darah yang terkontrol secara adekuat. Hal ini banyak yang meneliti tentang faktor yang memperparah retinopati diabetic. Penelitian yang dilakukan oleh (Dewi et al., 2019) menjelaskan tentang tingkat keparahan retinopati diabetik disertai hipertensi atau tanpa hipertensi, dengan menggunakan metode penelitian deskriptif observasional retrospektif dengan besar sampel yang dipilih melalui kriteria inklusi dan ekslusi berjumlah 162 yang memiliki data rekam medik pasien yang mengalami retinopati diabetik di RSUD Djamil Padang.

Dalam penelitian ini kurang dijelaskan tentang analisa data secara lengkap karena hanya menyajikan data berupa presentasi dari responden yang diteliti tiap variabel. Namun didalam hasil dan pembahasan penelitian (Dewi et al., 2019) menyebutkan tingkat retinopati terbanyak ada pada stadium PDR (Proliferative Diabetic Retinopathy). Hasil analisis menunjukan bahwa pasien diabetik retinopati dengan hipertensi ditemukan tingkat keparahan yang paling sedikit sebanyak yaitu mild NPDR (Proliferative Diabetik Retinopathy) sebanyak $58,1 \%$ dan paling banyak yaitu PDR sebesar $69,6 \%$, sedangkan pasien retinopati diabetik tanpa hipertensi ditemukan tingkat keparahan retinopati diabetik paling kecil yaitu PDR sebanyak 30,4\% sedangkan paling besar yaitu Mild NPDR sebanyak 41,9\%. Hal ini Putri Nirmala Dewi, 2019 mengambil kesimpulan bahwa tingkat keparahan retinopati siabetik terbanyak ada pada pasien dengan hipertensi dengan tingkat keparahan pada stadium PDR (Proliferative Diabetic Retinopathy).

Pasien diabetes mellitus dengan kontrol tekanan darah yang tidak adekuat akan meningkatkan resiko komplikasi mikrovaskuler, meningkatkan resiko yang memperburuk fungsi penglihatan dan meningkatkan resiko Progresifitas retinopati diabetic dibanding dengan pasien diabetes mellitus dengan tekanan darah yang terkontrol 
secara adekuat. Beberapa penelitian tentang faktor resiko retinopati diabetic salah satunya dijelaskan pada penelitian yang dilakukan lis Noventi, 2018 di Surabaya, Jawa Timur.

Penelitian yang disajikan oleh (Noventi \& Damawiya, 2018) juga menjelaskan bahwa penelitian ini bertujuan untuk menentukan faktor-faktor resiko yang dapat meningkatkan progresitifitas Diabetik retinopati, penelitian ini adalah sebuah studi kasuskontrol yang dilakukan pada pasien Diabetes mellitus di RSMM Jawa Timur selama 3 bulan dianalisis. Kasus dan kontrol yaitu pasien dengan NPDR(Non Proliferatif diabetic retinopati ) dan PDR (proliferative diabetic retinopati) masing-masing 30 pasien dengan menggunakan desain penelitian deskriptif retrospektif. Besar Sampel yang telah dipilih melalui kriteria iklusi dan ekslusi sebanyak 60 orang yang merupakan pasien diabetic retinopatik.

Penelitian ini menjelaskan bahwa pasien diabetes perempuan dengan dyslipidemia, umur $>30$ s.d $<85$ tahun, dengan lama menderita 1-50 tahun mempunyai resiko mengalami NPDR. Sedangkan pasien diabetes mellitus laki-laki yang mempunyai hipertensi dan disiplidemia, umur $\geq 40 \mathrm{~s} . d<65$ tahun, dengan lama menderita diabetes mellitus 1-20 tahun mempunyai resiko keparahan Diabetik retinopati stadium PDR. Penelitian lis menyatakan bahwa hal Ini menandakan penegakan diagnosis retinopati diabetic sedini mungkin perlu dilakukan upaya skrining rutin pada diabetes mellitus edukasi dan promosi kesehatan seperti penyuluhan tentang informasi retinopari diabetic seperti faktor-faktor yang menyebabkan retinopati diabetik sehingga diharapkan dapat meningkatkan kesadaran penderita DM akan bahaya komplikasi retiopati diabetik.

Penelitian yang dilakukan oleh (Syawal et al., 2019) juga menjelaskan tentang faktor- faktor yang menyebabkan penurunan ketajaman penglihatan pasien diabetes mellitus. Metode penelitian ini adalah deskriptif korelasional dengan pendekatan cross sectional, jumlah sampel pada penelitian ini sebanyak 45 orang pasien yang Puskesmas Biringkanaya. Penelitian ini menurut peneliti masih kurang dalam menyampaikan informasi mengenai kriteria inklusi dan eksklusi. Pengambilan data dilakukan menggunakan koesioner dan dilanjutkan dengan pengukuran visus untuk mengetahui ketajaman penglihatan pasien.

(Syawal et al., 2019) menjelaskan faktor-faktor yang berhubungan dengan penurunan ketajaman penglihatan pasien Diabetes Mellitus adalah pasien yang memiliki gula darah yang tinggi, usia dengan kategori dewasa lanjut, jenis kelamin perempuan, dan pasien Diabetes Mellitus yang memiliki komplikasi lain, dan lebih lanjut dijelaskan dari semua faktor tersebut orang yang memiliki komplikasi adalah faktor predominan dengan penurunan ketajaman penglihatan pasien Diabetes Mellitus.

\section{KESIMPULAN}

Berdasarkan Studi Literatur yang telah peneliti lakukan tentang "Hubungan Hipertensi dengan Ketajaman Penglihatan Pada Penderita Diabetes Mellitus Tipe 2", dapat disimpulkan bahwa terdapat hubungan hipertensi dengan penurunan ketajaman penglihatan.

\section{SARAN}

1. Penelitian selanjutnya dapat dilakukan pada tatanan yang berbeda dengan memodifikasi keterbatasan yang ada pada penelitian study literatur ini

2. Bagi peneliti selanjutnya diharapkan mampu memperhatikan faktor-faktor, variable dan metode penelitian lain yang dapat menurunkan ketajaman penglihatan.

3. Disarankan kepada peneliti selanjutnya diharapkan mampu memperhatikan variabel lain yang berkontribusi menurunkan ketajaman penglihatan.

\section{UCAPAN TERIMA KASIH}

1. Ketua Jurusan Keperawatan Poltekkes Kemenkes Makassar yang telah memberikan kesempatan melakukan penelitian

2. Direktur Politeknik Kesehatan Kemenkes Makassar yang telah memberikan kesempatan melakukan penelitian

3. Rekan-Rekan peneliti yang telah berkontribusi dalam memberikan informasi kepada peneliti terkait karya-karyanya berupa buku-buku, jurnal dan artikel lainnya yang mendukung penyusunan penelitian ini

4. Rekan/teman-teman dosen yang telah memberikan masukan dan motivasi dalam penelitian ini

\section{DAFTAR PUSTAKA}

(Kementerian Kesehatan Republik Indonesia, 2018)Annisa, Y., \& Romdhoni, M. fadhol. (2017). Perbandingan Resiko Terjadinya Retinopati Diabetik antara Pasien Hipertensi dan Non Hipertensi yang Mengidap Diabetus Mellitus di RSUD Majenang. Medisains, 31-38. http://jurnalnasional.ump.ac.id/index.php/medisains/article/download/1625/2110 
Hipertensi pada di RSUP Dr. M. Djamil Padang. 8(2), 204-210.

Kedokteran, F., Indonesia, U., Pendidikan, P., Spesialis, D., \& Mata, I. K. (2014). Fakultas kedokteran universitas indonesia program pendidikan dokter spesialis ilmu kesehatan mata jakarta, 2014.

Kementerian Kesehatan Republik Indonesia. (2018). Peta Jalan Penanggulangan gangguan penglihatan di Indonesia Tahun 2017-2030. In 2019. http://www.p2ptm.kemkes.go.id/dokumen-ptm/buku-peta-jalanpenanggulangan-gangguan-penglihatan-di-indonesia-tahun-2017-2030

Kurniawan, C. (2018). Komplikasi Pada Mata Karena Diabetes, Pencegahan dan Penanganan Diabetes Pada Mata. Andi.

Noventi, I., \& Damawiya, D. (2018). Faktor Risiko Retinopati Diabetika : A Case - Control. 10(2), 1-10.

Noventi, I., \& Damawiyah, S. (2018). Faktor Resiko Retinopati Diabetika. The Indonesian Journal of Health Science, 10(2), $1-10$.

Rahmawati, \& Amiruddin, A. (2017a). Glycohemoglobin, Hipertensi, IMT Terhadap Gangguan Penglihatan Penderita Diabetes Mellitus Lansia. 13 No. 1, 58-64.

Rahmawati, R., \& Amiruddin, A. (2017b). Glycohemoglobin, Hipertensi, Imt Terhadap Gangguan Penglihatan Penderita Diabetes Mellitus Lansia. Media Kesehatan Masyarakat Indonesia, 13(1), 58. https://doi.org/10.30597/mkmi.v13i1.1582

Shiddiq, R., Widodo, W. H., \& Poernomo, B. (2011). Hubungan Hipertensi Dan Glycohemoglobin (Hba1c) Dengan Kejadian Retinopati Diabetik Pada Penderita Diabetes Melitus Di Rsud Margono Soekarjo Purwokerto. Mandala of Health, 5(3), 356-360.

Syawal, Hamzatun, Ramlah, \& Awaluddin, S. W. (2019). Faktor Yang Berhubungan Dengan Ketajaman Penglihatan Pasien Diabetes Melitus Tipe 2 Di wilayah Kerja Puskesmas Biringkanaya Kota Makassar. Media Keperawatan, 09 No 02.

Utami, D. R., Amin, R., \& Zen, F. (2017). Karakteristik Klinis Pasien Retinopati Diabetik Periode 1 Januari 2014 - 31 Desember 2015 di RSUP Dr . Mohammad Hoesin Palembang. Majalah Kedokteran Sriwijaya, 49(2), 66-74.

Yastina, S. D., \& Afriant, R. (2017). Artikel Penelitian Gambaran Kejadian Retinopati Hipertensi pada Penderita Hipertensi yang Dirawat di Bagian Penyakit Dalam RSUP dr. M. Djamil pada Bulan Januari-Desember Januari 2013. Bagian IImu Penyakit Dalam FK Unand/RSUP Dr. M. Djamil Padang, 6(3), 602-608.

Yunia, A., \& Romdhoni, M. fadhol. (2017). Y. Annisa, M.F. Romdhoni. 15(1), 31-38. 